\title{
PROYECCIONES EFÍMERAS. LA CIUDAD AL OTRO LADO DEL VELO
}

\author{
Ángel Martínez García-Posada \\ Departamento de Proyectos Arquitectonicos. Universidad de Sevilla \\ https://dx.doi.org/10.12795/astragalo.2017.i23.10
}

Hace ya unos años, en 1994, con motivo de la controversia generada por un proyecto del arquitecto Álvaro Siza en el centro de Granada, la delegación de Urbanismo del Ayuntamiento requirió al maestro portugués la construcción previa en el solar de una maqueta a tamaño real que emulara las fachadas y el volumen del futuro edificio, y supeditó la concesión de licencia para las obras al levantamiento de este simulacro desmontable. Inicialmente, los responsables del proyecto, Siza y su colaborador en Granada, el arquitecto y profesor Juan Domingo Santos, aceptaron la fórmula como una vía pragmática para desbloquear la situación, dada la incertidumbre que parecía haberse suscitado acerca del impacto visual de la futura volumetría acabada. Dos décadas más tarde, cuando el conocido como edificio Zaida lleva años construido e incluso se diría que es relativamente asumido por la ciudad, que centra sus polémicas recurrentes en otros escenarios (estos mismos arquitectos lo están sufriendo con la descabellada campaña en contra de su proyecto para los nuevos accesos a la Alhambra), puede resultar oportuno recordar la historia, por ser tristemente ejemplificativa de la forma en que algunos entienden la arquitectura y la ciudad, entonces como ahora; y al tiempo, por su valor de creativo consuelo, sugerente estímulo para algunas reflexiones acerca de la escena urbana y la materialidad efímera, como las que este artículo pretende.

En aquellos días los medios habían difundido diversas suspicacias en torno al anteproyecto, emplazado en una manzana de Puerta Real donde antes había estado el hotel Zaida. La oposición política y ciertos colectivos que se arrogan la potestad de defender el patrimonio urbano, en definitiva, voces que no conocían en profundidad tales asuntos, alertaban de que el 


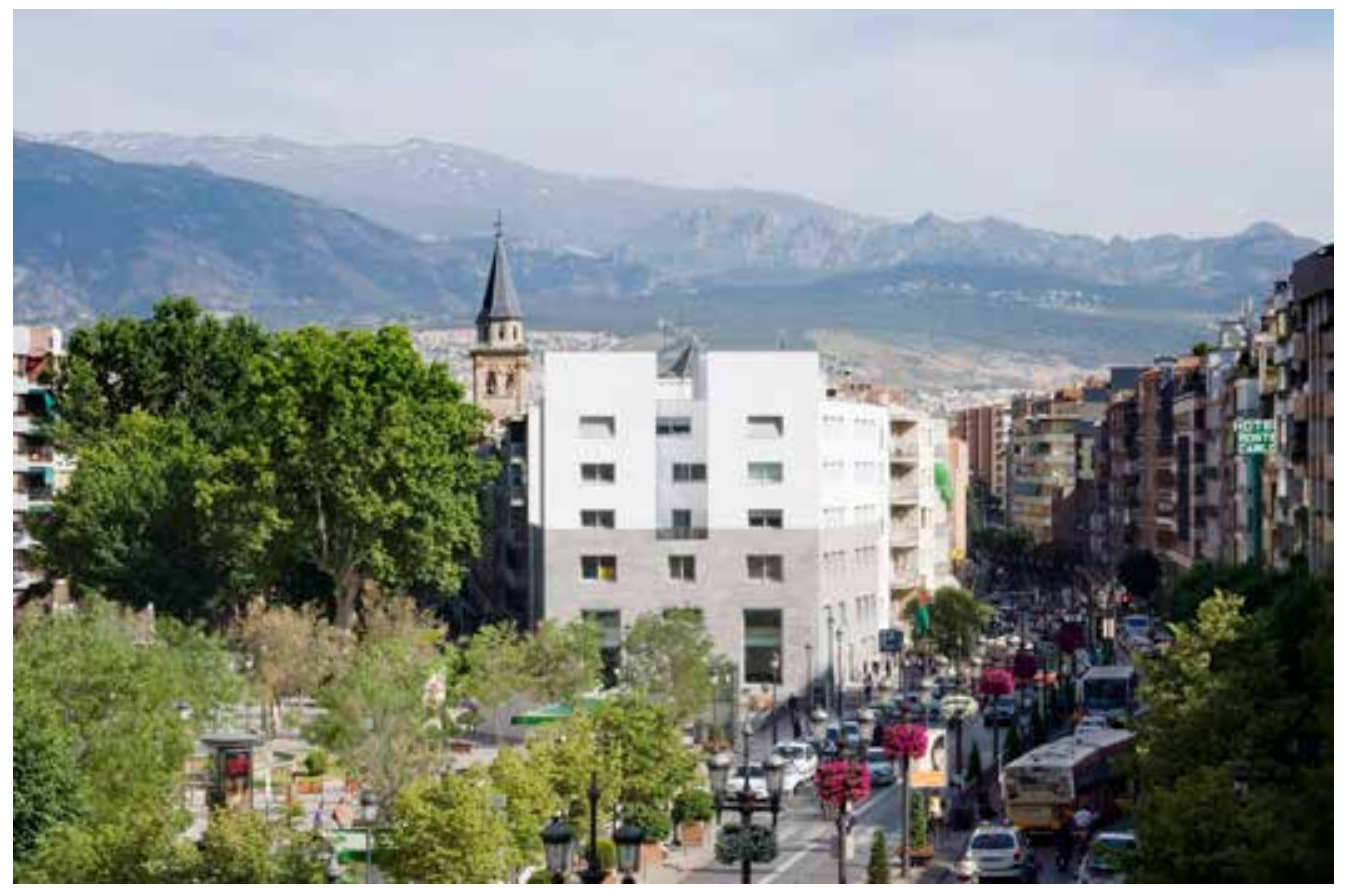

01 Imagen urbana del edificio Zaida en Granada. Fotografía: Juan Domingo Santos.

futuro edificio iba a tapar el panorama de Sierra Nevada. Se trataba más bien de un vergonzante ejercicio de cinismo que encubría las verdaderas razones de la crítica: por un lado, los intereses políticos; por otro, la animadversión inculta a la arquitectura contemporánea que llegaba a afectar a uno de los arquitectos más reconocidos en el ámbito académico y profesional, internacionalmente respetado entre otras cosas por su sensibilidad contextual. El edificio planteaba un volumen máximo de seis plantas, igualando en altura la parcela a las construcciones que habían ido surgiendo alrededor. Cualquier otro proyecto, fuese interesante o pobremente tradicionalista hasta el cliché en el desarrollo de sus fachadas, hubiera constreñido por igual las supuestas vistas del paisaje. Si el lector conoce ese lugar, advertirá que cualquier edificio a lo largo de esa calle, Acera del Darro, en cualquiera de sus dos orillas, ocupa ya una altura semejante, colmata por igual la parcela que le es propia, e incide pues de la misma manera en la alteración de una estampa lejana. Frente a eso, cabría desde luego la opción bartlebyana de no edificar en absoluto, el proyecto de Siza hubiera sido tan cuestionable como cualquier otro edificio en Granada, que a nada que se levante unos metros por encima de la mirada del ciudadano supone un obstáculo hacia el territorio alrededor, la Vega como la Sierra. Pero, como decimos, la causa de este argumento esgrimido tan refutable, era la persistente condición de sospechosa, casi presunta culpable, que algunos juicios populares atribuyen a toda intervención arquitectónica en 


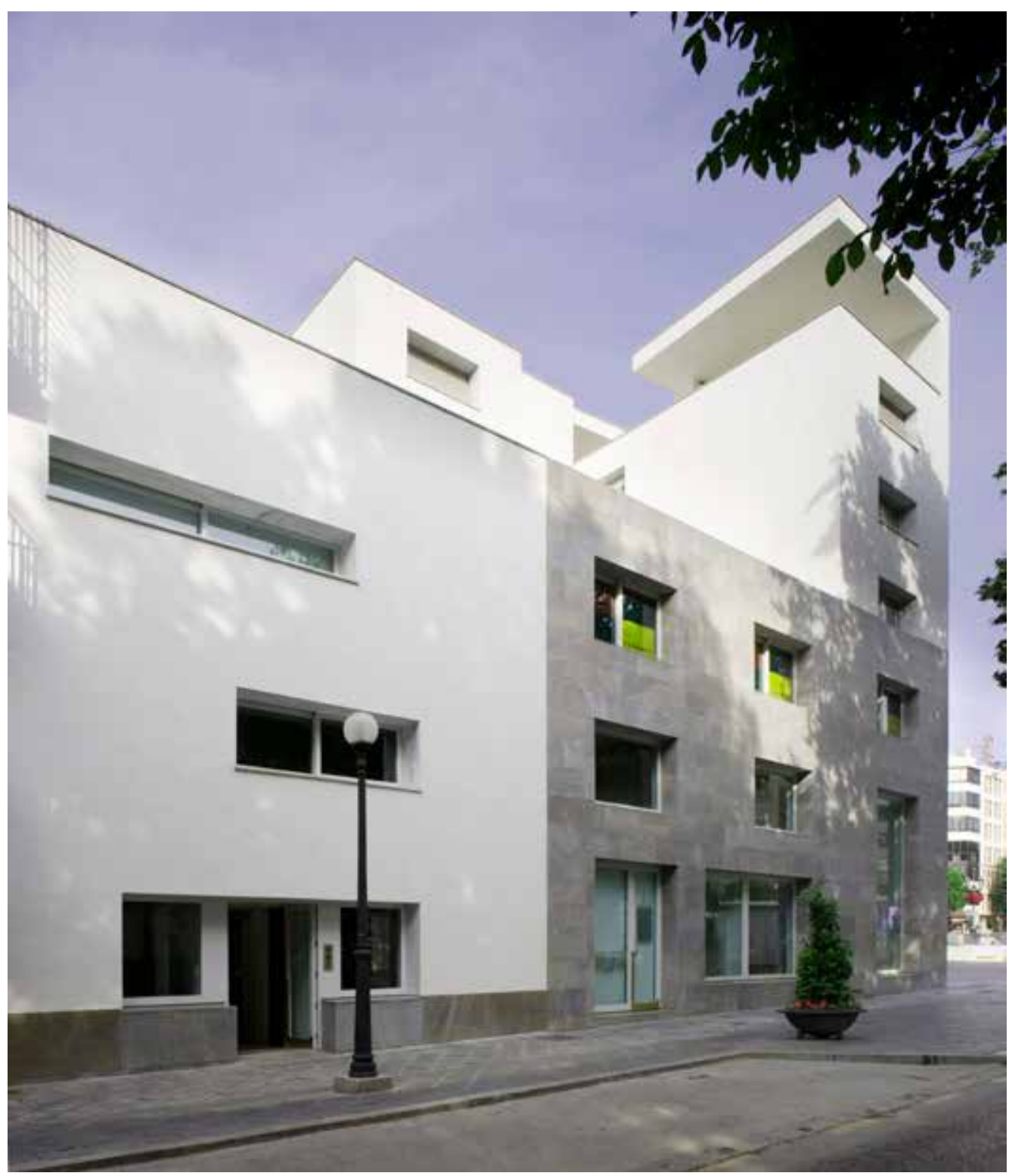

02 Frente del edificio Zaida a la plaza Bibataubín. Fotografía: Juan Domingo Santos.

un centro histórico que no apele a lenguajes imi- lamos el razonamiento de estas críticas a cualtativos de un cierto pasado, impostado, que se quier otro entorno urbano al margen del caso diera por inmutable, y además típico. Si extrapo- específico de Granada, podría alegarse que toda 


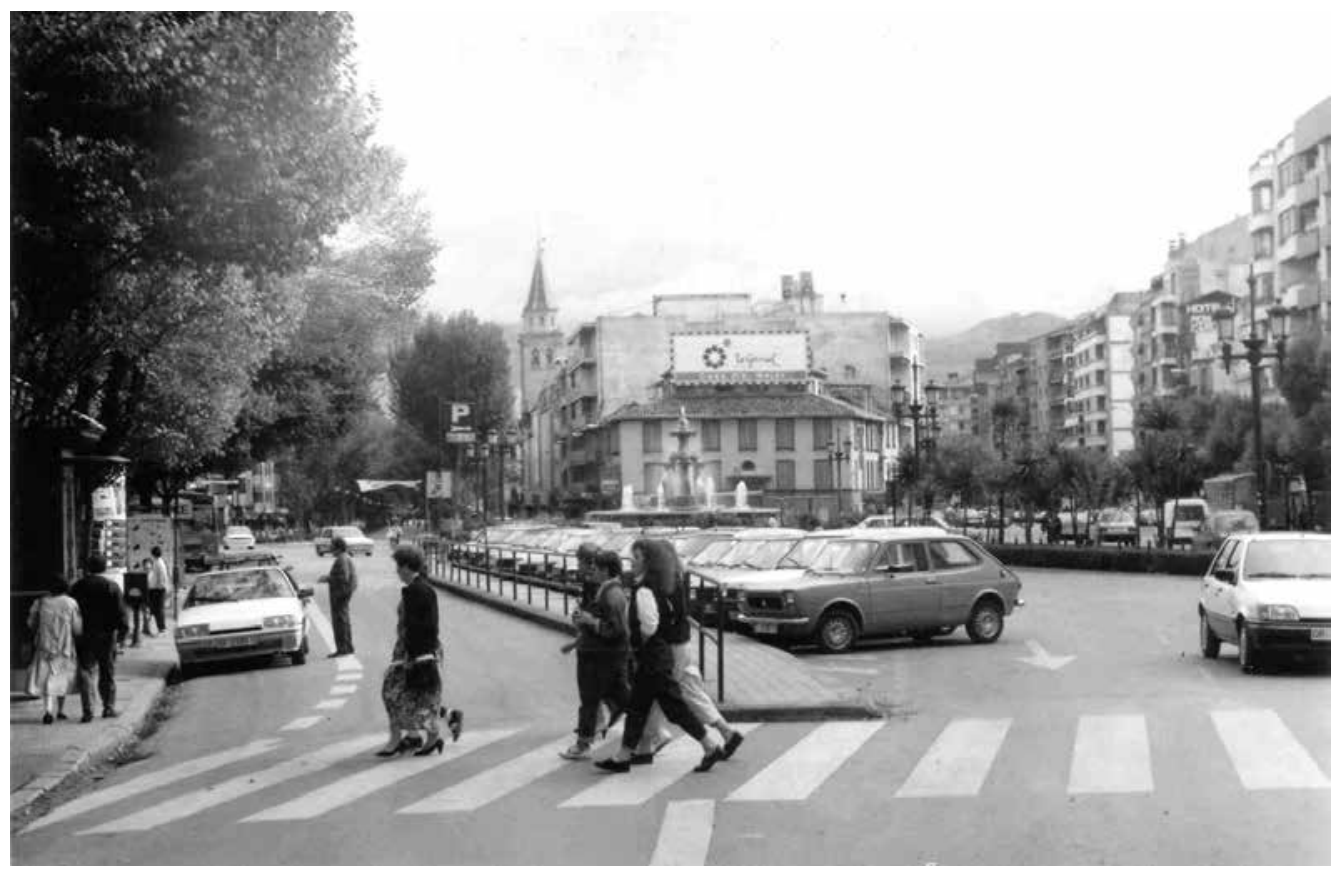

03 Antiguo Hotel Zaida en Granada.

forma que se alce ligeramente sobre el suelo, supone una innegable alteración de la plataforma original de la Tierra, y por tanto, una incidencia visual impugnable. Por todo ello, Juan Domingo Santos, hizo ver a las autoridades el sinsentido de aquel requerimiento, torticero o pacato según se mire, y consiguió que comprendieran que la construcción de aquella maqueta hubiera sido una aberración que habría convertido la ciudad en motivo de sorna en foros de prestigio. Es imaginable el absurdo que nuestras ciudades podrían llegar a ser, si cundiendo el ejemplo se llenaran de solares con telas provisionales, testando de este modo flácido la validez de ciertas formas antes de empezar a erigirlas con solidez, y hasta puede que esta postal distópica, sumada al eficiente denuedo cervantino del arquitecto en su explicación, convenciera a los munícipes in extremis. Y así finalmente desistieron del encargo de la maqueta 1:1, y el edificio pudo empezar a construirse con sus materiales definitivos.

El proyecto de Siza suponía un sutil ejercicio en torno al patrimonio edificado en la ciudad, en gran medida la polémica tuvo que ver con el diferente criterio de apreciación, respecto a lo fijado por las catalogaciones urbanas, de qué elementos de los preexistentes tenían o no interés. Siza proponía incorporar al conjunto una hermosa casa patio en un extremo, que sin embargo no estaba catalogada por la normativa, y en cambio proponía algunas alteraciones concernientes a lo que se requería preservar, y así demolía un par de casas existentes, una de construcción reciente y otra catalogada, pero sin interés alguno. En una sugerente conversación entre Álvaro Siza y Juan Domingo, publicada 


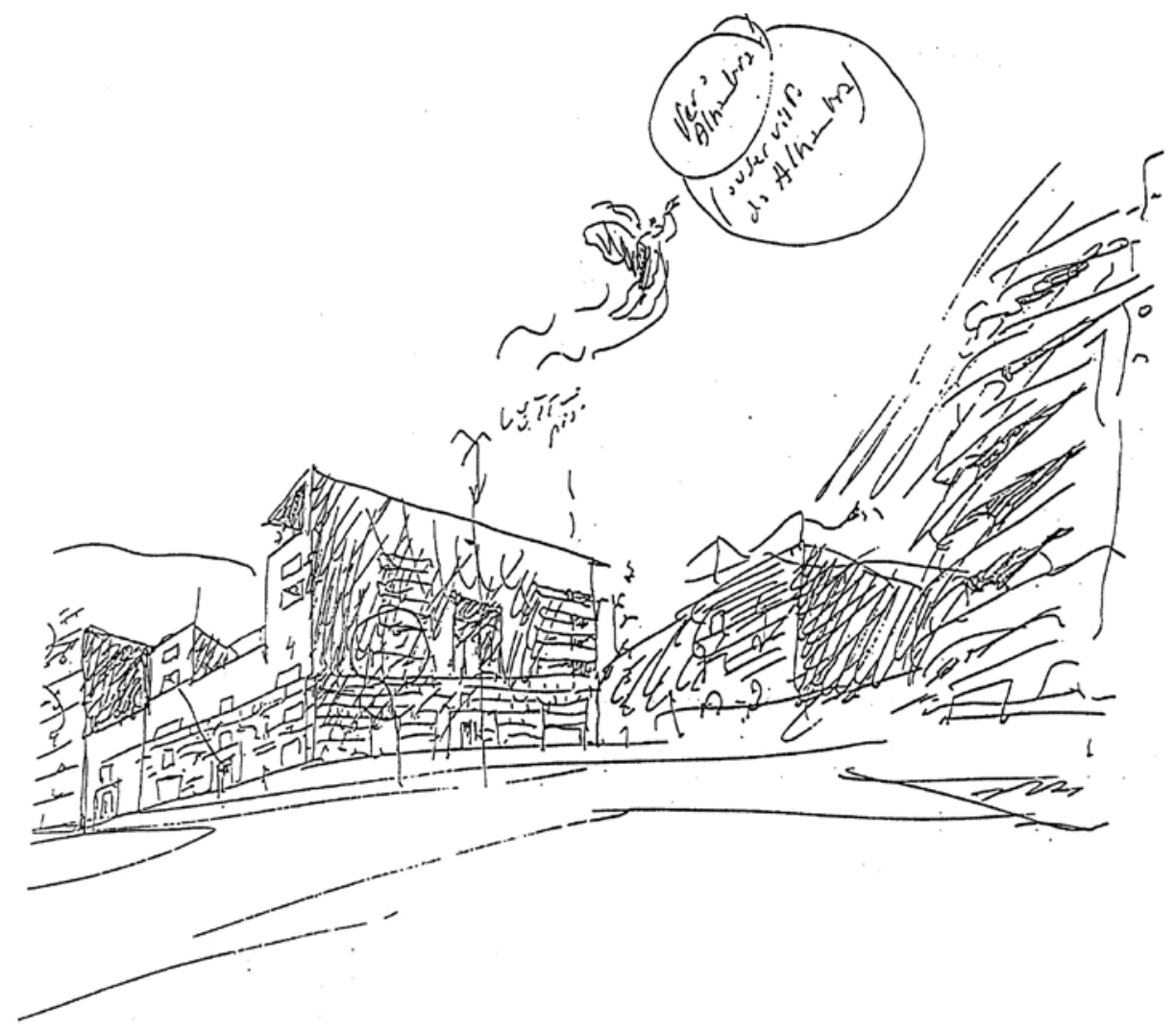

04 Dibujo de Álvaro Siza para el edificio Zaida.

con el título "Sobre la memoria de la ciudad y algunas notas sobre Picasso", editada por el Colegio de Arquitectos de Cádiz, el arquitecto portugués razonaba algunas de sus decisiones y postulaba un entendimiento sensible del tiempo histórico en la ciudad, al contrario de la congelación fijada por las normas. El arquitecto granadino lo describía de este modo: "Me parece fascinante la relación que propones entre lo nuevo y lo existente. La forma de los volúmenes retranqueados del nuevo edificio Zaida hacia el boulevard están determinados por las alineaciones del patio de la casa antigua, y a su vez, la casa antigua con el patio se descubren por sorpresa en el interior del nuevo Zaida. Todo está muy relacionado, de manera que lo nuevo y lo anterior quedan indisolublemente unidos para siempre. Resulta muy interesante esta visión patrimonial de las cosas y los tiempos sin tener que recurrir a la restauración. Hay un modo de elaborar el proyecto de recuperación urbana desde el presente a través de estos enlaces que ponen de manifiesto situaciones tan diversas".

La implantación del Zaida es elegante y grácil, todavía luce en su parcela, sigue siendo un faro que destaca, en el mejor sentido, frente 


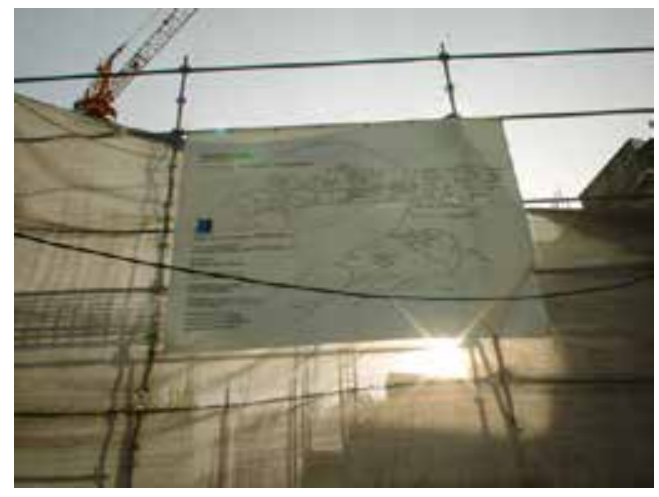

05 Dibujo de Álvaro Siza para el edificio Zaida colocado en la envoltura provisional de las obras. Fotografía: Juan Domingo Santos.

a otros edificios anodinos adyacentes. La envolvente edificada va cambiando de altura para adaptarse al frente de la plaza Bibataubín, o más allá al de la plaza Mariana Pineda, en torno a las tres alturas, y al de la Acera del Darro, con los seis niveles citados. Las fachadas del nuevo edificio son contenidas, con un aire loosiano, algunas de las voces críticas que hemos referido nos hacen también rememorar la reacción popular y mediática en aquella ciudad de Viena, en la bisagra entre un mundo antiguo y otro moderno, que Adolf Loos sufrió durante la construcción del edificio en Michaelerplatz, hace casi justo un siglo. Siza articula aquí esa doble materialidad característica de algunas de sus obras, la textura pétrea a modo de zócalo expandido hasta llegar a alcanzar la línea media del edificio, junto a la pureza del blanco geométrico del canon moderno, y acierta además a conjugar, como en algunos de sus mejores proyectos residenciales, esa dialéctica de las dos escalas, en un orden menor y mayor para los huecos, con esa contenida configuración de dos torres, cual dos esfinges abstractas. Hay algo en el marco grande de algunos huecos, o en la paridad de las dos esquinas elevadas, de la futura Iglesia de Marco de Canave- ses, como lo hay de la muy anterior Escuela de Arquitectura de Oporto en el pliegue de la visera del remate, o en la semántica de pabellón de algunas piezas, sobre todo la envoltura de la casa patio incorporada. Alguien interesado por la trayectoria de Siza podrá aventurar, hacia atrás y hacia delante, distintas conexiones subjetivas de este proyecto con algunos otros.

Siguiendo la razón constructiva de algunos de estos proyectos mencionados, Siza dispuso la piel con un muro de hormigón calado en sus huecos, que luego se trasdosaría con ladrillo con una cámara ventilada, y que a su vez habría de forrarse de piedra característica del lugar o enfoscarse de blanco, según se ha dicho. Ello explica también que, con cierta cautela comprensible, Juan Domingo, como socio local de Siza diariamente encargado de cuidar la ejecución del proyecto, sí decidiera construir durante la misma algo de aquella delirante maqueta que el Ayuntamiento había pretendido a priori: ante la certeza de que contaría con la observación, también diaria, de sus críticos, y ante el temor de que la constatación por parte de estos de aquella construcción de un muro de hormigón hubiera despertado de nuevo las reacciones por la incidencia visual que les servía de coartada en sus soflamas, optó por cubrir el proyecto con telas, sostenidas por un andamio oculto, edificando una caja envolvente, del mismo volumen aproximado que el edificio que habría de emerger, ocultando como con un telón los trabajos que se llevaban a cabo. El propio Siza había mostrado su contrariedad por esta veladura, pues ello le obligaba a replantear los huecos desde dentro, y le impedía poder testar el resultado, paso a paso, desde fuera. De este modo, solo al final, con el edificio muy avanzado, ya visible su forma última de planos en 
movimiento, con huecos que pudieran pensarse como ejecutados a la manera tradicional con fábrica de ladrillo, alféizares, mochetas, dinteles y carpinterías, estas cortinas fueron retiradas. La operación, quizás, tenía un aire de número de magia, por el recurso de los ilusionistas a tapar con un velo los resortes secretos de sus trucos.

Esta decisión de envoltura efímera del edificio mientras duraban las tareas constructivas conserva aún un resonante interés metalingüístico en el que este texto quisiera detenerse. Técnicamente resulta interesante ese artificio de construir un forro blando para un contenido sólido, también la solución híbrida de una membrana, la tela, y un esqueleto tubular, el andamio, que dotara al cierre del edificio de un espesor provisional mayor del que luego habría de tener, en su vocación de permanencia con la aplicación de la eficiencia del hormigón empleado, como si durante unos meses, se ilustrara la historia condensada de la envolvente en arquitectura, pasando del espesor masivo y estructural de la piedra a la fachada libre y de espesor limitado del hormigón, aunque aquí la dureza relativa se invirtiera, pues frente a la contundencia de la piedra se proponía en cambio la flacidez del tejido. El singular empeño de ocultación parecía ilustrar esa sentencia poética de Paul Valéry, lo profundo es la piel. Cabría postular una filiación de este procedimiento con la representatividad de la escenografía barroca, el juego de realidad y artificio tan propio de esa época, pensemos en la confusión ensoñada de Calderón en su monólogo de Segismundo, o en la riqueza espacial de Las Meninas. El barroco recurrió por primera vez a una urbanidad dinámica, teatral, interactiva, y operó como no se había hecho hasta ese momento con la ico-

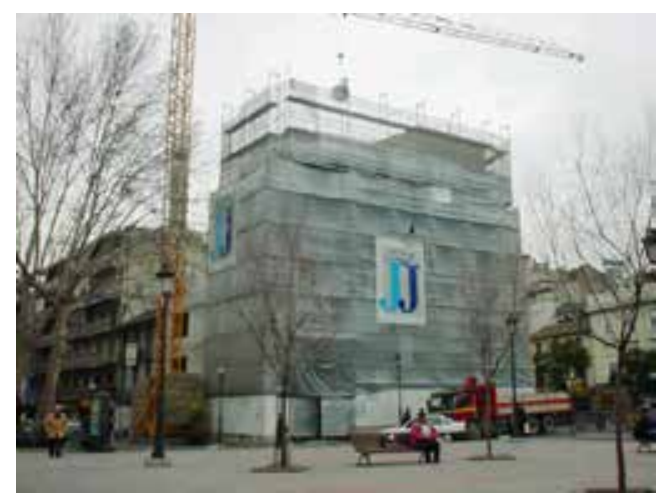

06 Envoltura de las obras del edificio Zaida. Fotografía de Juan Domingo Santos.

nicidad del telón urbano que las fachadas suponían, banda de intercambio entre espacios abiertos y cerrados, señalando que esa línea que separaba lo público de lo privado, podía configurar un escenario fundamental, altavoz para muchas historias. Igualmente, desde la taxonomía tipológica, el andamio como lugar habitable, o incluso el cerramiento de las obras, una suerte de provisorio ma orientalizante, ambos espacios intermedios y provisorios entre la capa final y el interior de los espacios, son ámbitos cuajados de potencial, y en la actualidad suponen un ávido campo de acción para la investigación arquitectónica y propositiva. Un andamio, mueble que antecede al posterior inmueble, es una entidad híbrida, entre el biombo y el estante, entre la cimbra y la escalera, que mientras es necesario se asemeja a la futura fachada ocultando en esta fase previa el espacio que algún día será. La fachada que será perenne incorporará luego funciones de aislamiento térmico o acústico a las que el andamio no ha de dar respuesta, pudiendo esencializarse pues hasta los huesos. También la fachada tendrá una función representativa de la que el andamio queda 


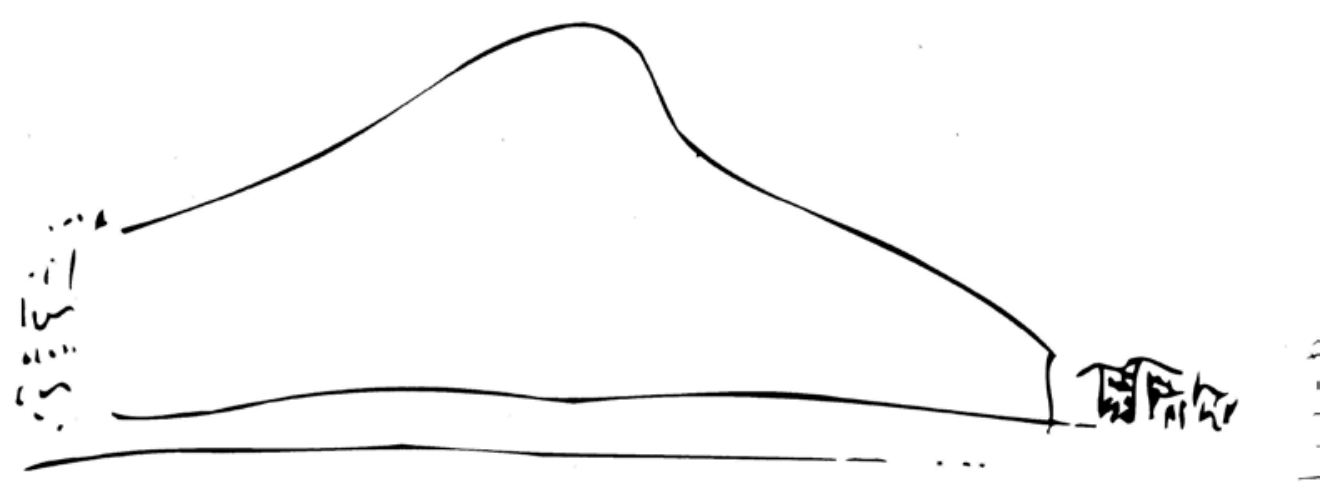

07 Dibujo de Álvaro Siza para el edificio de viviendas en Berlín.

exento, por eso su mera materialidad instrumental, con espesor pero todavía leve, admite otras posibilidades efímeras por indagar.

Junto a todo ello, esta suerte de estrategia vino a cargarse además de un intenso valor narrativo y metafórico: Juan Domingo decidió que las telas llevaran impresos un dibujo del propio Siza con la silueta del edificio. Por unos meses, en ese fino espacio vertical entre urbe y edificio, agitándose por acción del viento, pudo verse no tanto una imagen realística del bloque, aunque en parte podía servir como iluminación para descreídos, como sí un croquis, semilla primera de un largo proceso posterior hasta llegar a la fase constructiva, a la vez que recuerdo de la génesis del proyecto, rastro de la fe en el dibujo arquitectónico como primer gesto de transformación del mundo, que Siza acaso ejemplifica mejor que nadie. Sobre la tela ondulaba, como en una bandera gigante, la posición de convergencia entre pasado, presente y futuro que todo proyecto supone. Alguna vez he escuchado al propio Juan Domingo referir el modo en que Siza visita los solares de sus futuros edificios, y enseguida comienza a dibujar con sus dedos al aire las posibles siluetas de los mismos, al fin y al cabo, líneas fronterizas en mitad del cielo entre la ciudad y su arquitectura. Los dibujos posteriores de Siza en su tablero, tras este primer baile de las manos en el vacío, serían como la memoria en papel de aquellas intuiciones germinales. De este modo, en este relato granadino, grabado en las telas, podía verse en potencia el edificio dibujado, invirtiendo de paso la secuencia lógica de la arquitectura: todo proyecto supone el paso de las dos dimensiones del papel a las tres de la realidad, el paso del dibujo a la construcción; aquí existía en cambio una traviesa alteración de ese orden, una permuta de la habitual disposición en el tiempo de las distintas fases de un proyecto. Podríamos añadir que la estratagema estaba teñida de una fina ironía: con un sutil disimulo que ayudara a que el proyecto avanzara sin nuevas dilaciones provocadas por la intercesión de sus opositores, se estaba también relatando la propia historia sobrevenida al proceso normal de todo proyecto, cuando le había sido impuesto una maqueta en tela que permitiera evaluar el resultado del proyecto en la ciudad. Antes hemos especulado con la figura de Juan 
Domingo, en aquella reunión con el alcalde y su corte, como un hábil narrador que acababa venciendo reticencias políticas, ahora señalamos que con esta tela dibujada y transitoria que ocultaba un edificio, el arquitecto escribía también un cuento resonante.

Si quisiéramos seguir trazando asociaciones, podríamos comparar esta veladura pasajera con un caballo de Troya que alojara en su interior una suerte de engaño. Por sus posibles

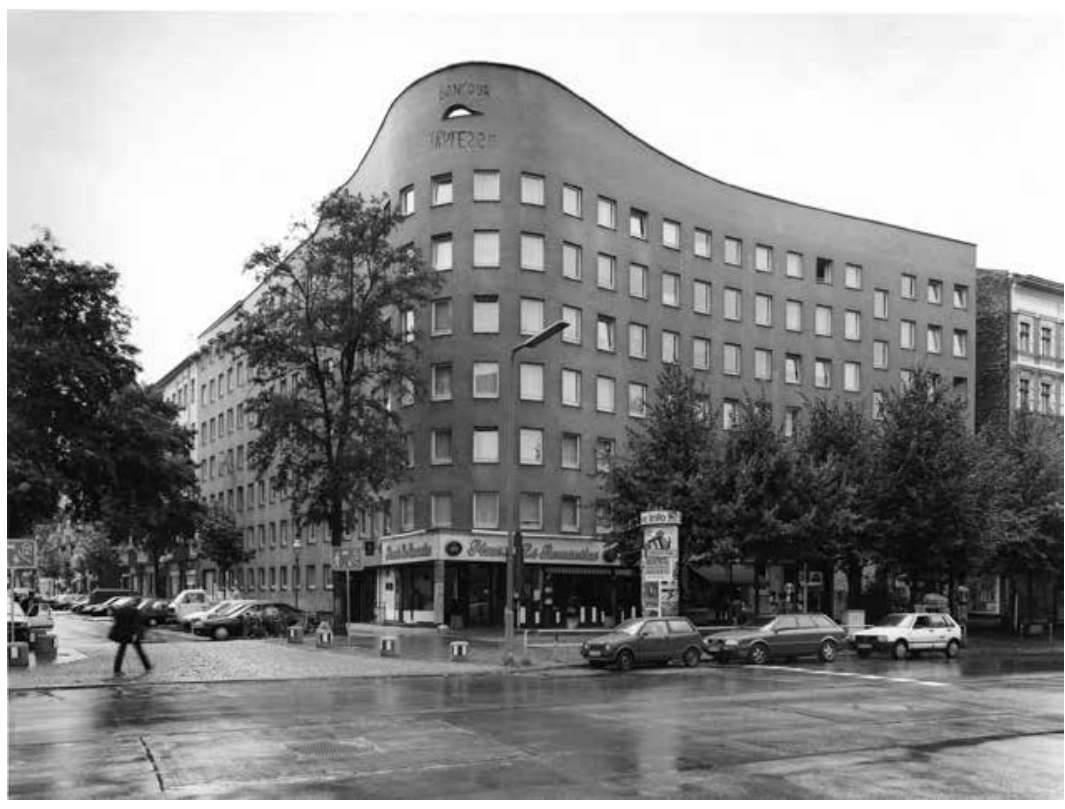

08 Edificio de viviendas Schlesisches Tor (Bonjour Tristesse), Berlín. similitudes con nuestras ciudades en fiestas, así la ciudad de Sevilla desde la que uno escribe, resulta una referencia fascinante la Sofronia que describiese Italo Calvino en Las ciudades invisibles, que a su modo puede leerse como una colección de relatos mitológicos a la par que urbanos. En esa Sofronia imaginada, la ciudad efímera era la de los edificios y no la de la feria. En cierta ocasión, al mostrar a una viajera europea las velas blancas que en Sevilla se instalan en el estío y proyectan refugios en sombras sobre calles como Sierpes, para mí un luminoso y alegre símbolo infantil de mis vacaciones de verano, ella me relató sin embargo el triste recuerdo de su niñez en las ciudades de la antigua Yugoslavia durante la Guerra de los Balcanes, cuando los habitantes colgaban telones flotantes que cubrían las calles en algunos puntos hasta tocar casi el suelo, con los que trataban de protegerse de los fran- cotiradores que actuaban desde las ventanas de los edificios, impidiéndoles la visión al otro lado, pero dejando libre la circulación sobre el suelo, el territorio sobre el que se produce el movimiento cotidiano de la ciudad. Para ella la presencia transitoria de estos planos de color suspendidos introducía en la ciudad un nuevo tempo que condicionaba dramáticamente la actividad de las personas que transitaban por donde aparecían colgados. Más recientemente, en cambio, otra visitante me hacía ver entusiasmada y dichosa, la semejanza de los colores repartidos por la ciudad en abril, como en altares móviles, con algunos rituales urbanos que ella, ahora residente en Norte América, profesora errante en su edad adulta, recordaba de sus añorados primeros paseos en Vietnam.

Antes indicábamos que a lo largo de la colección de proyectos de Siza pueden recono- 


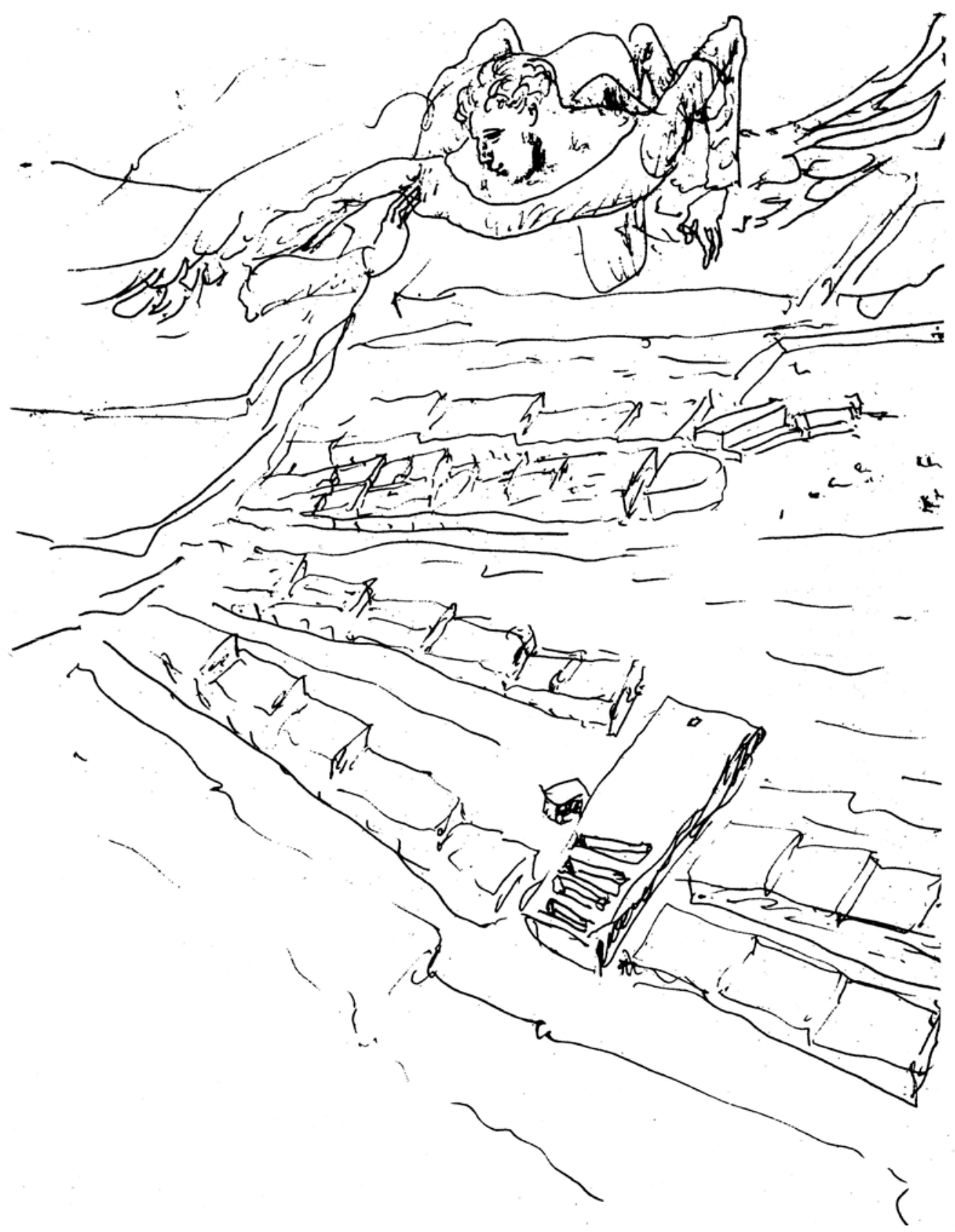

09 Dibujo de Álvaro Siza de Évora con el ángel. 
cerse ciertas formas inmanentes, y por encima de estas, una manera de mirar y dibujar el mundo. Podríamos relatar otros dos capítulos, uno en Berlín y el otro en Évora, afines a esta historia del gran velo granadino.

Una década antes de estas tribulaciones con el Zaida, Siza había sido invitado a construir un edificio en la muestra de viviendas de Berlín, en el barrio de Kreutzberg, que habría enseguida de hacerse célebre por un dibujo anónimo y reivindicativo, un graffiti caligráfico que escribía "Bonjour Tristesse" sobre su acabado blanco. En otra conversación entre los dos arquitectos, esta editada por la revista El Croquis en uno de sus números dedicado al arquitecto luso, Siza relataba a Juan Domingo el incidente de este modo: "En una de las visitas de obra el arquitecto Peter Brinkert, que colaboraba conmigo en el proyecto, me esperaba en el aeropuerto preocupado. Le dije que fuéramos a ver la obra y él me respondió que mejor al día siguiente. Yo le insistí porque tenía interés en ver cómo iban los trabajos, pero lo notaba muy reticente y al final me confesó que había algunos problemas, razón por la cual decidí acercarme rápidamente por allí. Al llegar vi la pintada mientras él esperaba atento mi reacción. Estuve largo tiempo mirándola y claro que me irrité. Sabía que formaba parte de una campaña muy dura por parte de grupos minoritarios de extrema derecha. Pero no contra el proyecto. Era en contra de todos los proyectos que estaba desarrollando la IBA, organismo que fomentaba el diálogo con los inmigrantes turcos. Había grupos extremistas que luchaban en la calle contra la policía, todo muy duro. Me irrité porque era absolutamente imposible hacer la pintada a aquella altura; cada obra tenía un guardia armado con un perro y, por tanto, era imposible subir y pintar sin la connivencia previa con el guardia. También estaba esa cosa ridícula de escribir la "S" y la "J" al revés para sugerir que el pueblo era inculto y no sabía escribir. Quedé muy irritado al principio con todo eso. Después pensé qué hacer, porque el color del edificio formaba parte del revoco y si picábamos el trozo afectado se notaría, ya que surgiría una discontinuidad con el resto de la fachada. Por otra parte, la solución de pintar todo el edificio de nuevo era impensable económicamente. Entonces decidí dejarlo tal y como estaba; y así se quedó. Más tarde el edificio fue portada de la revista Lotus y la pintada se convirtió en un símbolo. En algún momento se llegó a decir que yo había mandado colocar allí aquel graffiti para llamar la atención; nunca fue así". La narración ejemplifica que a veces los edificios construyen también sus propias historias. Existe un hermoso dibujo previo de este bloque berlinés, un boceto similar al que en el caso del Zaida ocupó el cerramiento efímero de la parcela durante las obras, en el que Siza abstrae la propuesta a apenas una línea sinuosa que separa el blanco edificado del cielo testigo sin distinguir huecos, como si la fachada fuera tan solo una tela blanca en la que no fuera relevante el calado menudo de ventanas. Si hemos consignado que los edificios alientan a veces historias también sucede que algunos relatos se entrelazan en el tiempo. Ese dibujo berlinés parecía anticipar la futura envoltura textil provisional del proyecto de Granada.

Esa consideración de la fachada como un velo, la del dibujo de Berlín o la de la acción de obra de Granada, nos hace evocar otro dibujo anterior, uno de los más simbólicos de Siza. Cuando en los años setenta el arquitecto estaba trabajando en Évora en las viviendas de la Quinta da Malagueira, años antes que en Berlín 


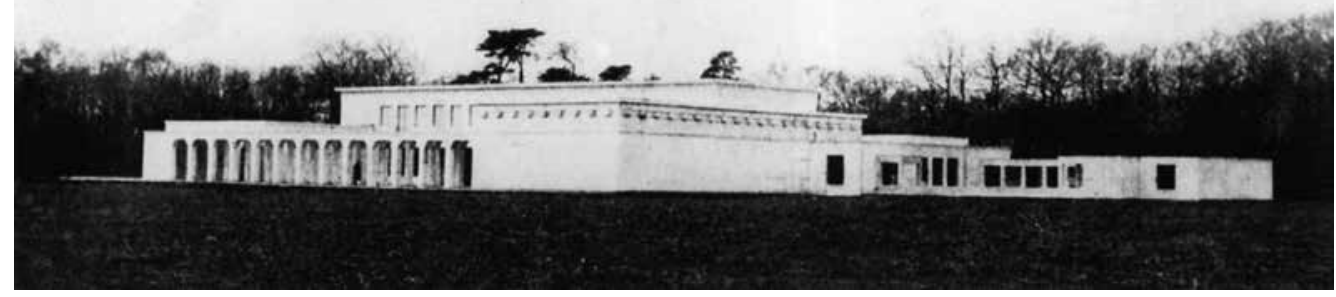

10 Maqueta en tela a escala 1:1 para la Casa Kröller-Müller de Mies van der Rohe.

y por tanto que en Granada, dibujó esta ciudad y colocó sobre ella la figura de un ángel que desplegaba una sábana. Esta veladura, según refería Siza, quería convocar la interacción entre la mirada y el dibujo: al cubrir con ese manto fino el territorio se insinuaban sus características fundamentales que iban dando lugar a sus arquitecturas, como el ejercicio de leer la vida abstraída en los trazos de la palma de la mano. Puede que el boceto berlinés del edificio como una cortina, recortada en su remate como una ola, fuera también un modo sutil de oponerse a la barrera sólida del Muro entre el este y el oeste, que también afectaba a ese barrio de Kreutzberg, y que pronto habría de demolerse. Hemos apuntado al inicio el indiscutible valor contextualista de Siza. Cierta vez, con finura y saudade, llegó a enunciar esta deliciosa paradoja: "Me gustaría construir en el desierto del Sahara. Probablemente, al comenzar los trabajos de edificación, alguna cosa aparecería, retrasando la prueba de la gran libertad: pedazos de cerámica, una moneda de oro, el turbante de un nómada, dibujos indescifrables grabados en la roca. En mi tierra no hay desiertos. ¿Y si los hubiese? Probablemente estaría condenado a construir un barco cargado de memorias, próximas o distantes hasta la inconsciencia: invenciones. Y si el barco se posase en el fondo de mar, estaría rodeado de ánforas, esqueletos, anclas irreconocibles bajo el óxido. Experimentaría el disgusto de ser llamado, incluso en el Sahara, o en el fondo del mar, contextualista". En otra ocasión explicó: "la tradición es un desafío a la innovación, está hecha de injertos sucesivos, soy conservador y tradicionalista, me muevo entre conflictos, compromisos, mestizaje y transformación".

Todas estas narraciones de envolturas efímeras permitirían también la glosa de una historia parcial, efímera o textil, de la arquitectura y la ciudad. Se ha referido alguna vez, así Juan Navarro en La habitación vacante, la importancia en la carrera de Mies de su inicial experimentación europea en proyectos de exposiciones para la industria del vidrio y de la seda. Mies sí llegó a construir una curiosa maqueta en lona a escala real en una parcela: cuando sedujo a una clienta de su mentor Peter Behrens para poder proyectar la Casa KröllerMüller en torno a 1912, por deseo de esta hubo de levantar la ficción de la apariencia futura de la casa usando una parihuela de madera sobre la que dispuso unas telas. Valentín Trillo, autor 


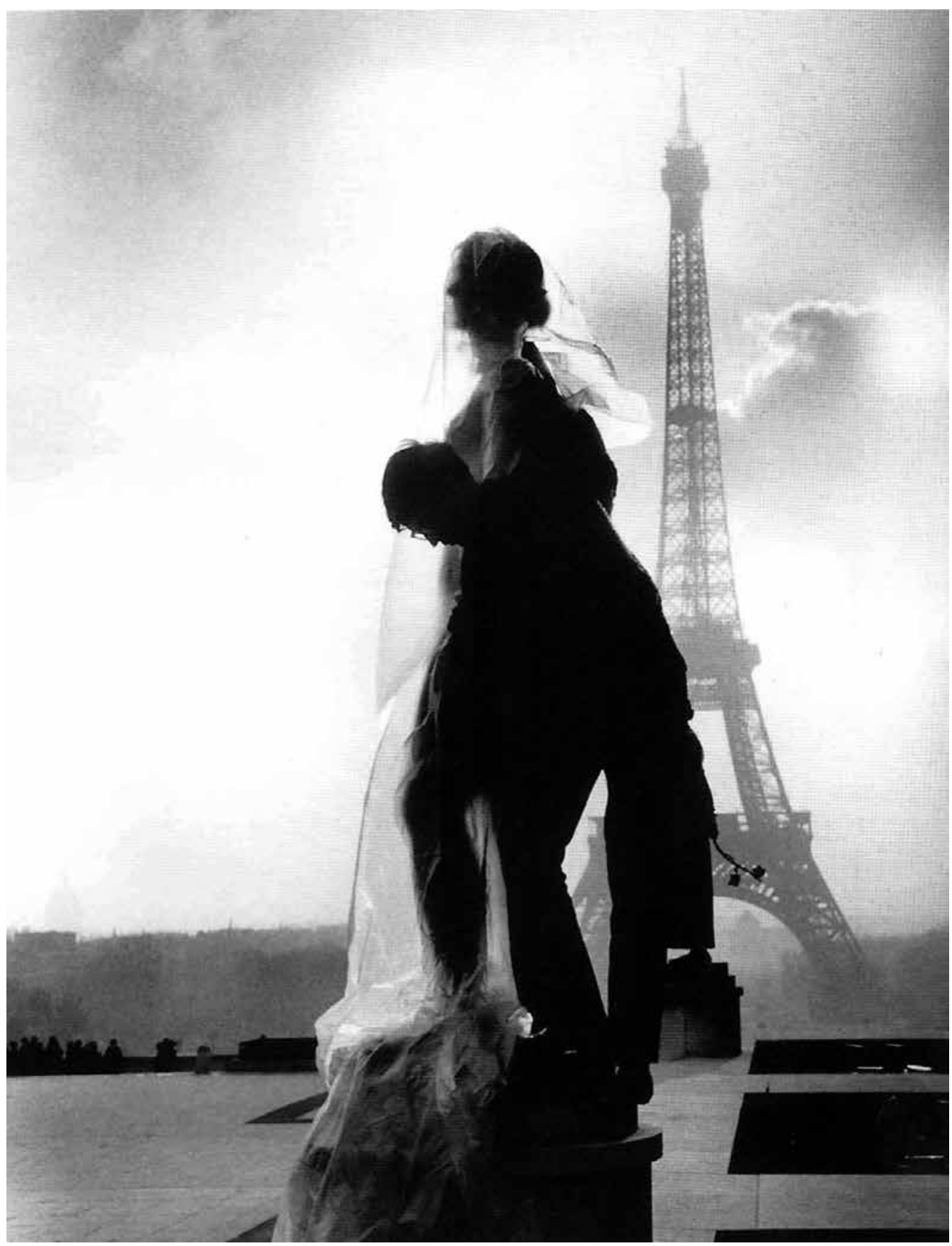

11 Christo envolviendo una de las estatuas de la plaza de Trocadero, París, 14 de febrero de 1961. Fotografía: Harry Shunk. 


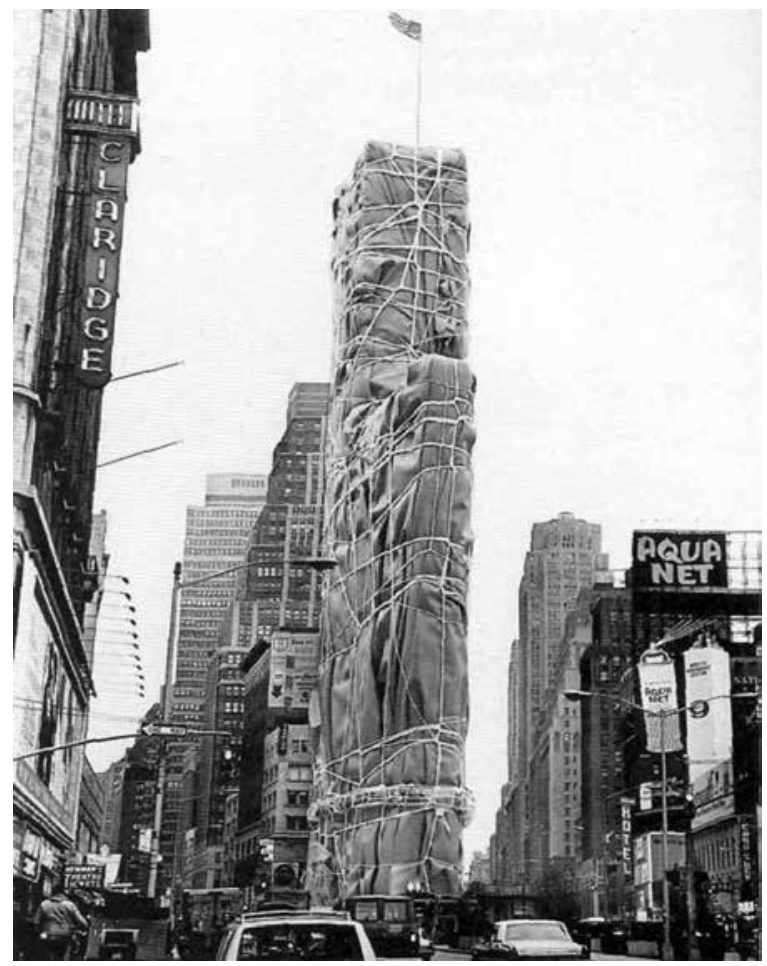

12 Christo y Jeanne-Claude. Wrapped Building, Project for Allied Chemical Tower, Times Square, Nueva York, 1968. Detalle de fotomontaje, $45,7 \times 25,4 \mathrm{cms}$.

de la tesis doctoral Mies en Barcelona. Arquitectura, representación y memoria, reflexionaba en su investigación sobre el ejercicio de exposición integral que aquello debió suponer: "Desde la generación de planos de la escenografía, decidiendo qué partes debían ser construidas para la visualización de conjunto y qué otras pasar a formar parte de la tramoya, a la elección del grado de detalle de representación según fuese a ser observada como conjunto o para ser recorrida a corta distancia, el despiece de materiales teniendo en cuenta las limitaciones dimensionales y la repercusión en el coste y transporte, los planos de detalle de ensamblaje, la gestión de un amplio equipo de operarios coordinados en poco tiempo, hasta el necesario plan de desmontaje y de reutilización material para la realización de aquel hito efímero instalado en un medio natural incierto".

Jorge Gorostiza, investigador acerca de las relaciones entre arquitectura, ciudad y cinematografía, publicó en 1999 en el boletín Circo, el texto "Pueblos de tela y cartón", cuyo título resulta ya afín a los asuntos que venimos desarrollando. En él recordaba la figura de Potemkin, que construyó para la zarina Catalina la ficción de un territorio cuajado de riqueza. "Quien sí entendía el poder de lo débil sobre lo fuerte e incluso de la ficción sobre la realidad, era Grigori Alexandrovich Potemkin, aquel político que construyó pueblos de tela y cartón (como los calificaba Adolf Loos) en los márgenes de los caminos de Crimea para hacer creer a Catalina la Grande que vivía en un país más urbanizado, más moderno, que aquella Rusia rural y atrasada en la que ambos estaban inevitablemente encerrados. Potemkin era un visionario que ya había descubierto en el siglo XVIII el uso que se le podía dar a las técnicas de la escenografía fuera de los teatros, en la realidad para suplantarla". La estrategia de Potemkin no era distante de todas esas comitivas que a lo largo de la historia de las ciudades han seguido recorridos engalanados ofreciendo a los gobernantes visitantes la mejor versión posible de los lugares de paso.

Son diversas las crónicas de engaños similares en el arte de la guerra. Durante la Segunda Guerra Mundial uno y otro bando recurrieron a este extraño maridaje entre estrategia bélica y práctica escenográfica. En El uso de las ruinas. Relatos obsidionales, Jean-Yves Jounnais da cuenta de una suerte de leyenda: "Se relata, 
desde el comienzo de la Segunda Guerra Mundial, una historia "de la que han llegado varias versiones hasta nosotros" de un falso aeródromo militar alemán construido en la Holanda ocupada para engañar a los observadores aliados. El campo de aviación, un meticuloso decorado, era íntegramente de madera. En él había hangares, depósitos de gasolina, vehículos y un centenar de aviones, como si fueran juguetes de tamaño natural. La realización de esta añagaza fue tan larga, pues se aspiraba a un realismo maníaco, que los aliados tuvieron todo el tiempo del mundo para seguir su realización y para comprender su verdadera naturaleza. Por eso, el último día de esta obra en marcha, mientras se fijaba la última tabla en el ala de un falso avión, otro avión, este inglés y de verdad, atravesaba el Canal de la Mancha y evolucionaba por encima de aquella escena de teatro antes de lanzar una bomba de madera".

Existe otro episodio paralelo de ciudad, inverso al anterior: el andamiaje replicante de Berlín construido en el desierto americano de Utah, el barrio alemán, levantado en 1943. Mike Davis lo ha referido con detalle en "El esqueleto de Berlín en el armario de Utah", incluido en su libro Ciudades muertas. Ecología, catástrofe y revuelta. El conjunto es todavía visitable, en cierto estado de reliquia ajada, si se consiguen los permisos oportunos. El ejército estadounidense reclutó en secreto al arquitecto Erich Mendelsohn para trabajar, con los ingenieros de Standard Oil y los diseñadores de la $\mathrm{RKO}$, con el fin de crear una ciudad en miniatura. La fuerza combinada del ejército, las petroleras y Hollywood logró concluirlo en menos de cincuenta días. En su proyecto Mendelsohn huyó de la arquitectura expresiva que había podido dejar edificada en Weimar antes del cam-
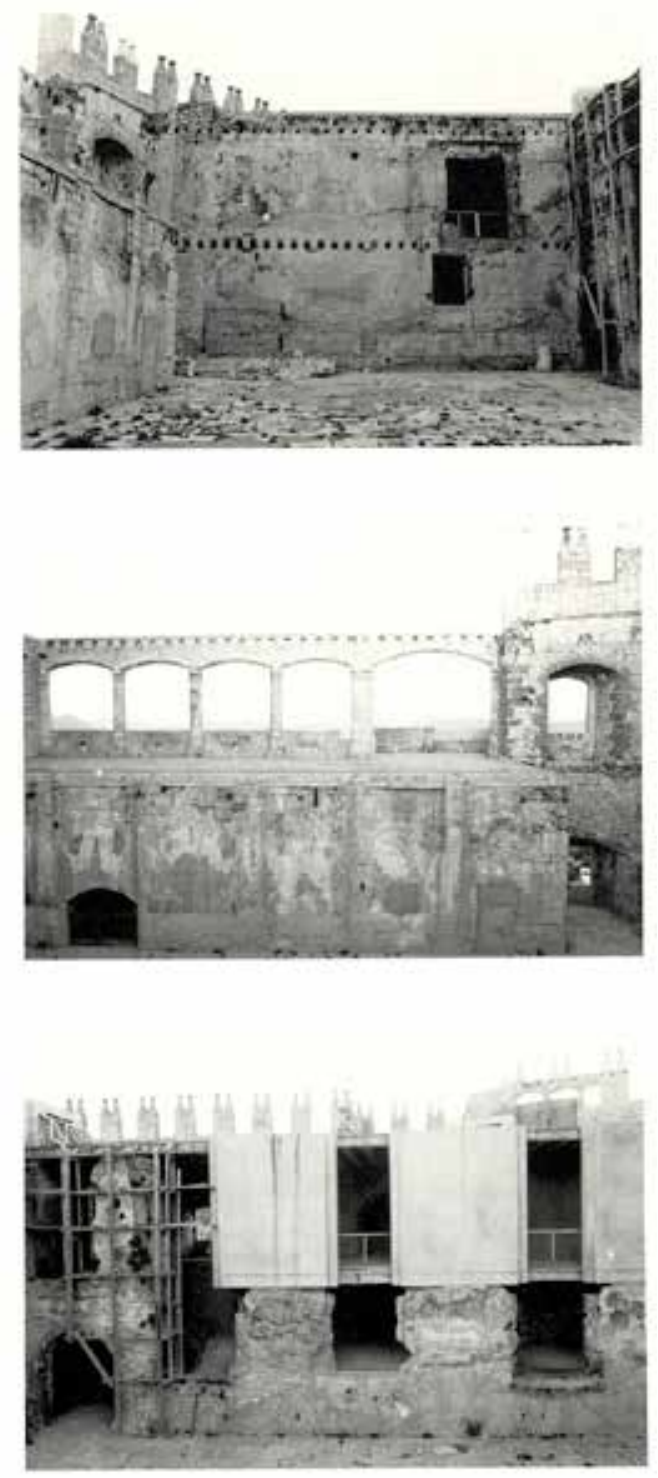

13 Montaje de la instalación de Soledad Sevilla en el Castillo de Vélez-Blanco.

tos falsos, despistando al enemigo con trucos de prestidigitador, haciendo desaparecer importantes objetivos vitales a su vista. Jounnais 


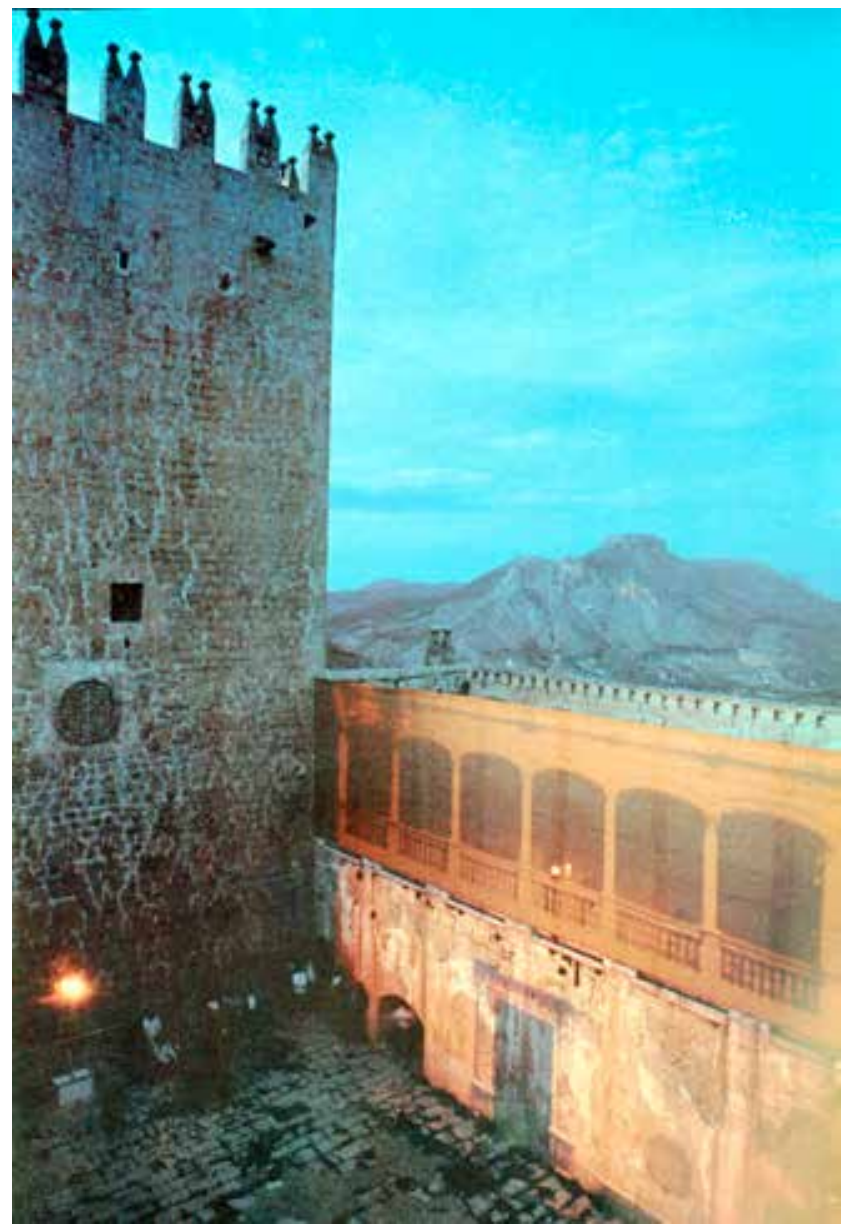

14 Instalación de Soledad Sevilla en el Castillo de Vélez-Blanco. nes atacantes, y este porcentaje no había dejado de aumentar. El propio espíritu del bombardeo estratégico era puesto en tela de juicio. El fracaso estaba cantado si no se encontraba nada que contrarrestase el sistema de radares alemán. Técnicamente, la respuesta fue de una asombrosa sencillez. Se recurrió a unas tiras de papel de aluminio, llamadas windows, de treinta centímetros de largo, reunidas en fajos de dos mil y sujetas mediante un brazalete de goma. Lanzados desde un avión, estos paquetes se dispersaban para formar una nube de tiras que producían en la pantalla del radar un eco análogo al de un avión. Lanzando uno de estos paquetes cada minuto, desde cada avión de la formación, se podía saturar la zona en observación por medio de unos ecos tan numerosos que se hacía imposible toda localización". Al margen del éxito del ingenio en términos bélicos, incluso al margen de la analogía con los trucos de los magos que venimos sosteniendo,

escribe en su libro antes citado otra historia semejante, a propósito de los bombardeos sobre Hamburgo: "La organización defensiva de esta ciudad, protegida por cincuenta y cuatro baterías pesadas antiaéreas y seis bases de cazas nocturnos listos para intervenir, había contenido hasta entonces las oleadas de bombardeos. En aquella época, la defensa alemana derribaba alrededor del cinco por ciento de los avioaquella imagen del batallón de espejitos sobre los cielos tuvo que resultar sublime.

También la historia del arte contiene algunos episodios urbanos y textiles concomitantes. Pensemos en las envolturas de Christo y Jeanne-Claude, sus conocidos wrappings, que suponen un diálogo tintineante con la rigidez de los edificios forrados. Christo había comenzado su carrera escultórica envolviendo estatuas 
clásicas en fundas de plástico transparente, inventando un espacio capturado visible en torno a los cuerpos congelados en piedra, como un halo, que luego sus tejidos sobre edificios, como la sábana del ángel de Siza, habrían de trasladar con el valor añadido de la escala. Había algo en ello que movía a evocar la emocionante reflexión que Marguerite Yourcenar escribió para el emperador en Memorias de Adriano: "La palabra escrita me enseñó a escuchar la voz humana, como las grandes actitudes inmóviles de las estatuas me enseñaron a apreciar los gestos. En cambio, y posteriormente, la vida me aclaró los libros". Algunas fotografías han conservado el retrato del artista protegiendo las esculturas parisinas de Trocadero. De vuelta a la contingencia de la guerra tan alejada de la especulación artística, me hacen pensar en esas protecciones de algunos monumentos para evitar su destrucción, como la instantánea de la fuente de la diosa Cibeles sepultada bajo sacos de arena, o las imágenes de archivo de esas pieles de ladrillo que se edificaron a lo largo de Italia para proteger temporalmente algunos hitos. Aquellas acciones primeras de Christo, junto a su admiración por el perfil de las ciudades, con Nueva York como paradigma, le harían viajar desde las estatuas a las construcciones cuando propuso por primera vez la envoltura de dos edificios del bajo Manhattan, aunque estos nunca fueron más allá de los dibujos. Su llegada a la metrópoli en los años sesenta había marcado el comienzo de su interés por la escala arquitectónica. En 1966 propondría otros tres proyectos irrealizados: la envoltura del MoMA, del Museo Whitney y de un edificio en Times Square. Entonces habría de ver sólo ejecutada su cubrición para otra construcción de Chicago. Sería otra de sus envolturas, la de 1 millón de metros cuadrados de la costa de Sídney (1 milla y media de costa) la que consolidaría el salto de tamaño en su trabajo. Lo más sugerente de aquel proyecto clave en su trayectoria, se aprecia mejor en vídeos que en fotografías, la fábrica se movía incesantemente. Luego vendrían el Valley Curtain de Colorado, una cortina colgada de tela de 76.200 metros cuadrados, la gran valla de California, una barrera de tela de 6 metros de alto y $39.4 \mathrm{~km}$ de longitud, y por supuesto el forraje textil del Reichstag, emblema de emblemas del siglo pasado.

Podemos pensar también en otra acción efímera, la instalación que Soledad Sevilla llevó a cabo a propósito del patio renacentista andaluz que ahora ocupa, como un espejismo, una de las salas más impresionantes y extrañas de esa colección de tesoros del mundo que es el museo Metropolitan de Nueva York, singular episodio de expolio artístico. A principios de siglo, el patio fue vendido, piedra a piedra, a un anticuario para acabar en una de las salas del museo neoyorquino, en un expediente de piedras desplazadas. En 1911 George Blumenthal, presidente del Metropolitan, lo había comprado para la sala central de su nueva casa en Park Avenue. Trowbridge y Livingston, arquitectos de la mansión Blumenthal, construyeron un edificio sobrio, de influencia italiana, que se adaptara bien a las formas del Castillo del Marqués de Vélez. En 1941, Blumenthal decidió cederlo al museo, el patio fue desmantelado y los dos mil bloques de piedra del patio catalogados y almacenados, a la espera de su traslado a la sede museística. En 1964 aprovechando la remodelación y ampliación del edificio fueron colocados finalmente como lo visitamos hoy. A Soledad Sevilla la visión del patio renacentista de Vélez-Blanco en aquella sala le produjo una sensación de extra- 


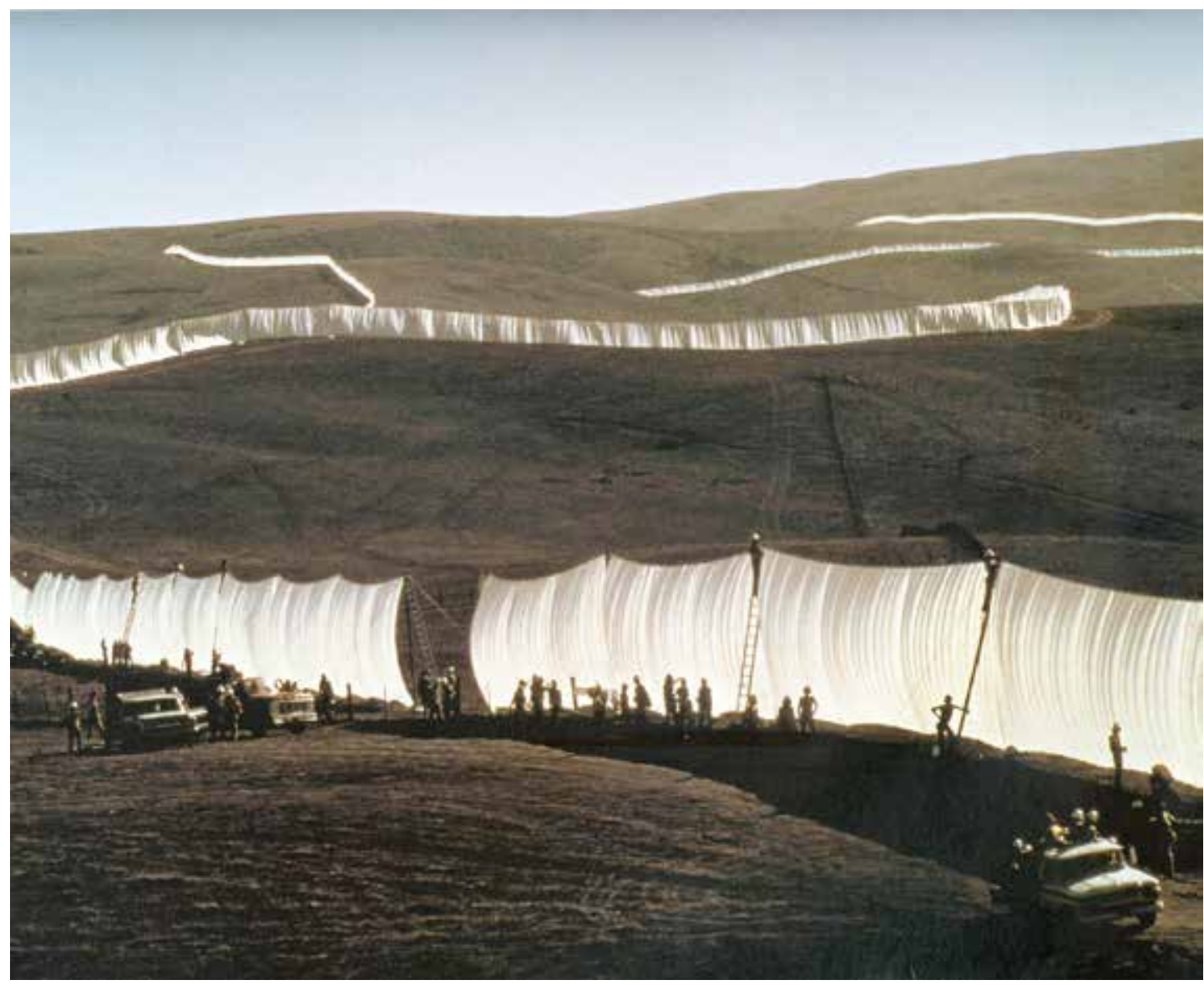

15 Christo y Jeanne-Claude. Running Fence, Condados de Sonoma y Marin, California, 1972-1976. 216.000 metros cuadrados de nylon de 5,5 metros de alto a lo largo de 39,4 kilómetros.

ñamiento y desgarro, así concibió para el castillo la instalación a la que nos referimos con motivo de la Exposición Universal de 1992. Sobre las paredes desnudas del patio devastado fueron proyectados los elementos arquitectónicos y decorativos originales. La artista pretendía convocar, como en un conjuro, la presencia perdida del patio, devolver lo sustraído proyectando sobre los muros en ruinas el esplendor que había sido expoliado. Comenzó a trabajar en 1991, foto- grafiando los tres lados expuestos en el museo que habría de restituir mediante la proyección, eliminó de las fotografías cualquier rastro museístico ajeno a la situación primigenia, rigurosa labor de recuperación de la verdad histórica. En el emplazamiento original redispuso telas para ocupar la volumetría mermada por el expolio, cubrió algunos huecos de puertas o ventanas, instaló un andamio y una pantalla que cubriese el vano de la galería del segundo piso del ala 
este, eligió para la tela un color que se integrara con la piedra para la mínima alteración de la ruina. Durante tres días, en el ocaso, se iniciaba la proyección para que la luz solar en su progresión hacia la oscuridad fuera dejando aparecer con lentitud el aspecto original del castillo. A la caída de la tarde, se encendían los proyectores y la imagen empezaba a percibirse lentamente. Esa suave verdura que el crepúsculo permitía iba intensificándose a medida que avanzaba la noche. Con la completa oscuridad, la fusión entre paredes desconchadas y la imagen proyectada hacía pensar que ese hueco descarnado acogía lo que le perteneció en una emocionante síntesis entre realidad y ensoñación.

Aludíamos con anterioridad al potencial representativo de andamios o cerramientos de obra, que Juan Domingo supo utilizar de un modo poético. Según exponía Marshall Berman en Todo lo sólido se desvanece en el aire. La experiencia de la modernidad, Robert Moses fue el primero que comprendió el valor de realizar las obras públicas como si fuesen espectáculos públicos: "Cuando llevaba a cabo el reordenamiento de Central Park, la construcción del parque zoológico y su estanque trabajando veinticuatro horas diarias, durante los siete días de la semana, brillaban los focos y refulgían los martillos mecánicos durante toda la noche, con lo que no sólo se aceleraban las obras, sino que también se creaba un nuevo espacio de representación que mantenía cautivado al público". La justicia poética de la estrategia granadina del Zaida es distinta a la razón práctica de Moses, el gran responsable del crecimiento metropolitano de Nueva York durante décadas, pero ambos casos señalan el valor escenográfico de la materialidad efímera de las obras. También lejos de la lírica del dibujo de Siza al diferir la contempla- ción del edificio que encarnaría a la conclusión de las obras ese mismo dibujo, podríamos pensar en el carácter falsario de algunas fachadas como telones teatrales. Es sabido que en Dubai y otros emiratos donde el consumo energético no es, de momento, un problema, los edificios acabados pero vacíos, se mantienen encendidos aleatoriamente para asemejar una ocupación que no es real. También conocemos la sensación de decepción que los conquistadores cristianos de Sevilla pudieron experimentar al traspasar la gran muralla almohade que cercaba la ciudad que ellos pensaban colmatada y que resultó tener mucho de engaño o de arrogancia al figurar una grandeza mayor, ocultado en cambio un territorio lleno de huertas solo en parte edificado.

Esta misma teatralidad podría registrarse en aquellos frentes de fachada unificados que envolvían algunas plazas barrocas, dando imagen de unidad a lo que al otro lado era una mixtura heterogénea. Pensemos en la Place Vendôme que proyectara Jules Hardouin-Mansart. El gran arquitecto de la corte absolutista ideó un primer proyecto en 1685 con una serie de edificios públicos, como academias, biblioteca, casa de la moneda o embajadas, luego, en 1698 se derribaron las fachadas y se planteó un nuevo reciento más reducido en el que se erigieron de nuevo las fachadas. Al otro lado de las mismas solo había al inicio solares vacíos que se irían vendiendo a particulares. Mansart empleó entonces un basamento almohadillado sobre el que se levantan hoy columnas apilastradas de orden gigante, que proporcionan el ritmo a la plaza. La fachada igualitaria enmascaraba una amalgama, con apariencia de uniformidad, de viviendas particulares y edificios públicos, y era pues otro decorado urbano dirigido a la glorificación del Luis XIV, cuya estatua solía presidir 
los centros de aquellas plazas reales francesas. En este caso se colocó como centro focal una columna al modo de la de Trajano en Roma, en cuya parte superior figuraba la estatua en bronce del rey como Emperador.

La actualidad viene siempre a surtirnos de encuentros en el tiempo, como los que aquí han podido referirse. Recordemos también la máxima de Marx de la historia repetida como farsa. Tres tristes historias recientes, cada una a su modo, como hubiera dicho Tolstoi, vienen a entrelazar todos estos temas. Mientras repasaba este texto para su entrega definitiva hemos asistido al despliegue de la Policía Nacional en Barcelona. Cierta hostilidad local obligó a alojar a los agentes en grandes barcos atracados en el puerto, uno de ellos, dado que la improvisación del dispositivo no permitió encontrar una nave mejor, estaba cubierto con dibujos infantiles, pues había sido empleado como recinto de ocio infantil sobre las aguas, que ahora teñía todo de una contradicción elocuente. La sorna, en los medios y en las redes, por esta imagen surreal, no cabe pensar en una estampa más Dadá, provocó que al día siguiente se cubrieran con grandes telas blancas los dibujos pintadas en el casco, entre otros al pajarito Piolín. La escena me hizo acordarme de cuando mi madre cubría la jaula del canario con una sábana vieja para que este durmiera. También en estos días, hemos leído en prensa las propuesta de la Liga de Fútbol española de multar a los clubes que no eviten que en la retransmisiones televisivas de los partidos que se jueguen en sus estadios sea visible el hormigón vacío de sus gradas, y que el actual sistema de horarios y teletaquillas contribuye a vaciar. La Liga exige resituar a los espectadores en los fondos de escena de los enfoques de las cámaras, y también a cubrir con telas con espectadores ficticios dibujados sobre ellas. En su artículo satírico publicado en El País el pasado 24 de septiembre de 2017, Rosario G. Gómez escribía: "Para evitar que las gradas aparezcan desangeladas se contempla incluso la posibilidad de desplegar lonas. Aunque los clubes también podrían hacer como los italianos, que utilizaron olivos de cartón piedra para engañar a los inspectores que realizaban fotografías aéreas de los campos de cultivo y así aumentar fraudulentamente las subvenciones de Bruselas. En caso de urgencia, podrían colocar un croma con enfervorecidos hooligans". En estos mismos meses recientes algunos grupos críticos con el presidente Donald Trump han reclamado que se volviera a levantar la gran tela californiana de Christo y Jeanne-Claude, antes referida, en otro de esos contrastes entre los blando y lo duro, como un modo de ejemplificar el sinsentido del proyecto de muro con Méjico.

El poeta y traductor Ángel Crespo escribió este aforismo: "Debussy escribía en un espejo; Stravinsky, detrás del espejo; Schönberg, en el marco del espejo". Es plausible su extrapolación a cualquier otra disciplina creativa, pero en la traslación literal a una fachada urbana concebida como un telón efímero, permite una lectura arquitectónica: ciertos creadores reflejan la realidad visible, amparados en la revisión de algunas fórmulas tradicionales; algunos buscan el origen de los procesos de cambios, al otro lado de la convención; otros, reflexionando sobre las estructuras, habitan en el marco mismo que sostendría esa frontera. Varios relatos aquí recogidos tienen algo de esto tercero, y tal vez, algunos, ciertas dosis de lo primero o de lo segundo. Estas últimas noticias en los medios han venido a su vez a recordarme que en el otoño de 1994, justo al inicio de mi primer 
curso en la Escuela de Arquitectura de Sevilla, en ese metafórico despertar a la posibilidad de mirar las ciudades a uno y otro lado del velo, incluso en el mismo velo, guardé en mi colección de recortes, que entonces era todavía en formato físico, una crónica publicada en El País firmada por Alejandro V. García y que me produjo curiosidad y sorpresa. El título era "Siza, obligado a montar una maqueta gigante para poder construir en la Alhambra” y el subtítulo "El arquitecto simulará las fachadas para que se vea el volumen". Entonces, que empezaba a construir modestas maquetas, a apreciar la importancia de la herramienta intelectual de la escala, a comprender que proyectar es escribir el futuro de la vida que vendrá, pensé que si estudiar arquitectura tenía algún sentido era el de desarrollar la capacidad de saber jugar con el tiempo, hacia atrás o hacia delante, recorriendo mentalmente en sentidos inversos el trayecto que va del papel al lugar donde algún día se levantará nuestro diseño. Por ello aquella noticia que ahora recupero para dar acaso un cierre circular a este conjunto de historias urbanas, me resultó desconcertante. Una década después, ya de profesor, pude conocer a Juan Domingo, que ha sido desde entonces un admirado docente y arquitecto, amigo cómplice en muchos de estos relatos, y quien me ha contado, mejor que lo que esa crónica lo hacía, la historia de aquella ciudad efímera sobre la tela.

Justo al final de Las ciudades invisibles Marco Polo confesaba a Kublai Klan que cada ciudad comprende otras ciudades. El viajero explicaba al emperador que al referir una ciudad concreta, podemos estar hablando de otras muchas, porque "cada ciudad es una sucesión en el tiempo de ciudades diferentes, todas las ciudades futuras pueden estar ya presentes en este instante, envueltas las unas dentro de las otras (...) y cada ciudad se va pareciendo a todas las ciudades, los lugares intercambian forma, orden, distancias". Todas las historias alternativas de existencia efímera y velada que hemos ido consignando, de fortuna variable, serían tan ciudad como las que finalmente se construyeron. 


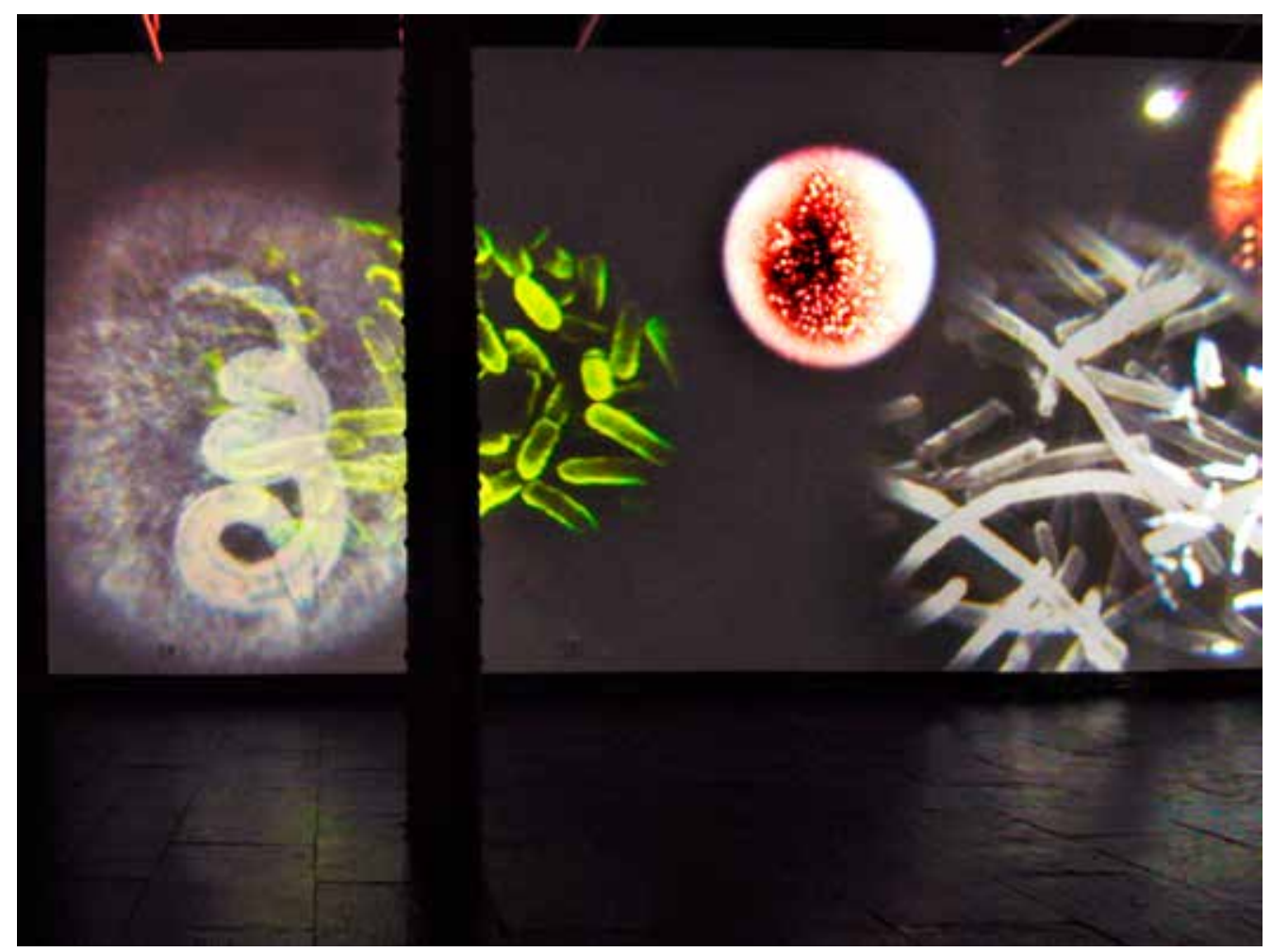

